\title{
IMPLIED CONSENT TO A CHEMICAL TEST FOR INTOXICATION: DOUBTS ABOUT SEGTION 6-205 OF THE UNIFORM VEHICLE CODE
}

Every state makes it a crime to drive "under the influence of intoxicating liquor." 1 Often, however, an arresting officer's recollection of the defendant's appearance and behavior is the prosecutor's only available evidence. ${ }^{2}$ Conviction is obviously facilitated by scientific evidence showing the motorist's blood-alcohol level at the time of arrest, ${ }^{3}$ and under many state statutes an alcohol content of .15 per cent or more raises a rebuttable presumption of intoxication. ${ }^{4}$ The chemical test can be made from a sample of the defendant's blood, breath, saliva or urine, ${ }^{5}$ but absent compulsion, suspects seldom supply such a sample. ${ }^{6}$

1 This is the standard in the UNIFORM VEHICLE CODE $\$ 11-902(a)$, and in most state statutes. See Slough \& Wilson, Alcohol and the Motorist: Practical and Legal Problems of Chemical Testing, 44 MinN. L. REv. 673, 674 n.2 (1960); Note, 37 N.D.L. REv. 212, 214 nn.17-21 (1961).

2 In Chicago, the officer fills out a form at the time of arrest and uses it to refresh his memory at the trial. He notes odor of breath, color of face, condition of clothes, use of profanity and appearance of eyes. Then if the suspect is willing to perform a set of tests the officer notes his ability to balance, walk, turn, pick up coins, etc. Chicago Police Department, Alcoholic Influence Report Form (1961). The suspect is also asked specific questions about injuries, illnesses or use of medication to preclude a subsequent alibi that they caused his condition. Cf. Donigan, Chemical Tests and THE LAW (Supp. 1961, at 3-11).

3 National Safety Council, Uses of Chemical Tests for Intoxication 1962; Dewey, Message of the Governor, 1954 McKinNey's N.Y. SEss. LAws 1341, 1342.

4 The UNIForar Venicle CoDE § 11-902(b) would reduce this content to .10\%. Conversely, most statutes also provide that a blood-alcohol level below $.05 \%$ shall indicate sobriety, but this is so low that as a practical matter few persons are freed who prosecutors could otherwise have convicted. Statutes are collected in Breithaupt v. Abram, 352 U.S. 432, 436 n.3 (1957); National Committee on Uniform Traffic Laws and Ordinances, Recent Developments in Chemical Test and Implied Consent LAws 1, 9-10 (April 24, 1963).

5 A detailed description of the tests is beyond the scope of this comment. See generally People v. Kovacik, 205 Misc. 275, 128 N.Y.S.2d 492 (Ct. Spec. Sess. 1954); Muehlberger, Chemical Tests to Determine Alcoholic Influence, in DonIGaN, op. cit. supra note 2, at 163-80 (Appendix 1957); Burgee, A Study of Chemical Tests for Alcoholic Intoxication, 17 MD. L. REv. 193, 194-200 (1957); Ladd \& Gibson, The MedicoLegal Aspects of the Blood Test to Determine Intoxication, 24 IowA L. REv. 191, 193-215 (1939); Slough \& Wilson, supra note 1, at 675-84; Note, 25 U. KaN. CITY L. Rev. $86,41-49$ (1956).

6 The courts have split on the admissibility of the fact of the defendant's refusal. In some states it may be considered as a circumstance tending to show consciousness of guilt. State v. Benson, 230 lowa 1168, 300 N.W. 275 (1941); Gardner v. Commonwealth, 195 Va. 945, 81 S.E.2d 614 (1954); City of Barron v. Covey, 271 Wis. 10, 72 
Police have been reluctant to take the sample without consent. The position of the New York attorney general is typical. "The safeguarding of the body of a criminal defendant from harm or attack is an important element in the administration of criminal law. I must advise you therefore that until the Legislature grants more specific authority your police should not use compulsion or bodily force to obtain the evidence referred to."7

Often, however, policemen at the scene of an accident find the driver unconscious but note suspicious signs that he has been drinking. In several such cases, realizing that the body oxidizes alcohol and thus in time destroys the evidence, officers have ordered that the sample be taken without waiting for the driver's consent. ${ }^{8}$ In Breithaupt 7. Abram, ${ }^{9}$ the Supreme Court affirmed a conviction based on the test of a blood sample drawn by a doctor in these circumstances.

Conscious motorists have less often had samples taken without their consent. ${ }^{10}$ Twelve states, however, have sought to obviate the need for actual consent by adopting a statute reciting that the act of driving itself constitutes an implied consent to submit to the chemical test. ${ }^{11}$ Under these statutes a person may withdraw this "consent," but only at the price of losing his driver's license. Section 6-205 of the Uniform Vehicle Code is representative:

N.W.2d 387 (1955). In others it is inadmissible to avoid penalizing the motorist for exercising a specific right to refuse the test. People v. Stratton, 286 App. Div. 323, 143 N.Y.S.2d 362 (1955) (right granted by New York version of § 6-205); State v. Severson, 75 N.W.2d 316 (N.D. 1956) (right granted by statute); Duckworth v. State, 309 P.2d 1103 (Okla. Crim. 1957) (right granted by judicial decision). These and similar cases are collected in State v. Munroe, 22 Conn. Supp. 321, 171 A.2d 419 (1961) (excluded because of no probative value). Because of this split, the UNIFORM VEHICLE CODE makes § 11-902(g), which allows comment, an optional provision.

71941 N.Y. ATr'y GEN. ANN. REP. 146.

8 See People v. Tucker, 88 Cal. App. 2d 333, 198 P.2d 941 (Dist. Ct. App. 1948); Block v. People, 125 Colo. 36, 240 P.2d 512 (1951); State v. Ayres, 70 Idaho 18, 211 P.2d 142 (1949); State v. Weltha, 228 Iowa 519, 292 N.W. 148 (1940); State v. Sturtevant, 96 N.H. 99, 70 A.2d 909 (1950); State v. Cram, 176 Ore. 577, 160 P.2d 283 (1945). The practice has continued, e.g., State v. Daugherty, 320 S.W.2d 586 (Mo. 1959); State v. Ball, 123 Vt. 26, 179 A.2d 466 (1962).

9352 U.S. 439 (1957), affirming 58 N.M. 385, 271 P.2d 827 (1954).

10 Contra, State v. Berg, 76 . Ariz. 96, 259 P.2d 261 (1953) (results admissible); People v. Kiss, 125 Cal. App. 2d 138, 269 P.2d 924 (Dist. Ct. App. 1954) (admissible); Apodaca v. State, 140 Tex. Crim. 593, 146 S.W.2d 381 (1940) (inadmissible); see United States v. Nesmith, 121 F. Supp. 758 (D.D.C. 1954).

11 Conn. Public Acts No. 616 \& (1963); IdAho Code ANN. § 49-352 (Supp. 1963); Kan. Gen. Stat. AnN. § 8-100I (Supp. 1963); Minn. Stat. ANN. \$ 169.123 (Supp. 1963); Neb. Rev. Stat. § 39-727.03 (1960); N.Y. Vehicle \& Traffic LAw \& 1194(1); N.C. GeN. STAT. § 20-16.2 (Supp. 1963); N.D. CENT. CodE \& 39-20-01 (Supp. 1963); S.D. CODE $\S$ 44.0302-2 (1960); UTAF Code ANN. § 41-6-44.10 (Supp. 1963); VT. Stat. ANn. tit. 23, $\S 1188$ (Supp. 1963); VA. Code ANN. § 18.1-55 (Supp. 1962). 
(a) Any person who operates a motor vehicle upon the public highways of this State shall be deemed to have given consent ... to a chemical test ... for the purpose of determining the alcoholic content of his blood if arrested for any offense arising out of acts alleged to have been committed while the person was driving ... a motor vehicle while under the influence of intoxicating liquor. The test ... shall be administered at the direction of a law enforcement officer having reasonable grounds to believe the person to have been [so] driving . . . .

(b) Any person who is dead, unconscious or who is otherwise in a condition rendering him incapable of refusal, shall be deemed not to have withdrawn the consent . . . .

(c) If a person under arrest refuses ... to submit to a chemical test ... as provided in paragraph (a) ... none shall be given, but the department ... shall revoke his license or permit to drive ....12

Such statutes have survived all constitutional attacks to date $e^{13}$ and have been unanimously praised in the law reviews. ${ }^{14}$ Drivers' arguments

12 The Uniform Vehicle Code was prepared by the National Committee on Uniform Traffic Laws and Ordinances. It has the support of the National Safety Council and was introduced, in substance, in twenty-four state legislatures in 1963. See National Committee, supra note 4, at 7. No analysis of construction problems is presented here. See generally Annot., 88 A.L.R.2d 1064; Weinstein, Statute Compelling Submission to a Chemical Test for Intoxication, 45 J. Crum. L., C. \& P.S. 541 (1955); Note, 49 VA. L. Rev. 386 (1963). See also the UnIform Chemical TEsT For IntoxicATION ACT $\$ \S 1-15,9$ U.L.A. (Supp. 1963, at 51-59), approved by the American Bar Association in 1957. 43 A.B.A.J. 1056 (1957).

13 State v. Bock, 80 Idaho 296, 328 P.2d 1065 (1958) (dictum); Lee v. State, 187 Kan. 566, 358 P.2d 765 (1961); Prucha v. Department of Motor Vehicles, 172 Neb. 415, 110 N.W.2d 75 (1961); Schutt v. MacDuff, 205 Misc. 43, 127 N.Y.S.2d 116 (Sup. Ct. 1954) (dictum); Timm v. State, 110 N.W.2d 359 (N.D. 1961) (dictum); Walton v. City of Roanoke, 133 S.E.2d 315 (Va. 1963). In addition, at least one court has suggested, without discussion, that its state legislature adopt such a law. State v. Wolf, 53 Del. 88 , 164 A.2d 865 (1960). In its original form, the New York implied consent law was struck down for failing to provide the driver a hearing before revocation. Sehutt $v$. MacDuff, supra. That has been corrected in all states, however, and subsequent objections based on procedural due process have failed. Finocchairo v. Kelly, 11 N.Y.2d 58, 181 N.E.2d 427, 226 N.Y.S.2d 403 (1962); Ballou v. Kelly, 12 Misc. 2d 178, 176 N.Y.S.2d 1005 (Sup. Ct. 1958); Anderson v. MacDuff, 208 Misc. 271, 143 N.Y.S.2d 257 (Sup. Ct. 1955); People v. Kovacik, 205 Misc. 275, 128 N.Y.S.2d 492 (Ct. Spec. Sess. 1954).

14 Slough \& Wilson, supra note 1, at 684-99; Weinstein, supra note 12; Note, 6 Baylor L. Rev. 404 (1954); Comment, 51 Mrch. L. Rev. 1195 (1953); Comment, 35 Texas L. Rev. 813 (1957); Note, 25 U. KaN. CrTY L. Rev. 36 (1956); Note, 49 VA. L. Rev. 386 (1963); Comment, 17 WASH. \& LEE L. REv. 299 (1960); Note, 1960 WAsh. U.L.Q. 84; cf. DonIGAN, op. cit. supra note 2, at 94-147; Ladd \& Gibson, supra note 5, at 215-41; Mamet, Constitutionality of Compulsory Chemical Tests to Determine Alcoholic Intoxication, 40 ILL. L. Rev. 245, 249-56 (1945); Comment, 23 TENN. L. Rev. 178 (1954). But cf., Comment, 1953 Wis. L. Rev. 351. 
may have failed, however, because they have raised only self-incrimination, due process or search and seizure objections which the courts have properly rejected on the basis of established doctrine. It is urged here that the federal constitutional issue would be more sharply posed by arguing that an incriminating sample of body fluid or breath submitted under the terms of the statute is analogous to a coerced confession.

Clearly the statutory recitation of implied consent does not change the issues involved. A legislature cannot consent on behalf of an individual if actual consent is really required, and the fiction of an act evidencing consent is not persuasive when the act is one so common as driving a car. ${ }^{15}$ The theory underlying state jurisdiction over nonresident motorists, ${ }^{16}$ sometimes cited as an example of implied consent, ${ }^{17}$ is not in point. The Supreme Court has dismissed the "implied consent" used there as "fictive talk" and recognized that "in point of fact . . . jurisdiction in these cases does not rest on consent at all... We have held that this is a fair rule of law ... and that the requirements of due process are therefore met ...."18 The chemical test statutes likewise do not involve actual consent; they present the question whether police can take from a person under lawful arrest a sample of blood, breath, saliva or urine-not by physical force-but by imposing a severe sanction for failure to cooperate.

Drivers' defenses based solely on the privilege against self-incrimination have not prevailed because that doctrine does not protect "real evidence."19 Nor have arguments based upon the "shocks the conscience" due process standard of Rochin $v$. California ${ }^{20}$ succeeded. That case involved evidence obtained by pumping a suspect's stomach against his will to recover morphine capsules. Under section 6-205 the physical taking of blood, breath, saliva or urine is a non-brutal process lacking the offensiveness of the course of conduct involved in Rochin.

Arguments that chemical testing constitutes an unreasonable search and seizure have likewise failed. ${ }^{21}$ One court held a breath test was not

15 See Note, Consent, Liability and Guilt: A Study in Judicial Method, 7 STAN. I. REv. 507 (1955).

16 See especially, Hess v. Pawloski, 274 U.S. 352 (1927), affirming 250 Mass. 22, 144 N.E. 760 (1924).

17 Timm v. State, 110 N.W.2d 359 (N.D. 1961); Commissioners' Prefatory Note, Uniform Chemical Test for Intoxication Act, 9 U.L.A. (Supp. 1963, at 51-52).

18 Olberding v. Illinois Cent. R.R., 346 U.S. 338, 341 (1953).

19 United States v. Nesmith, 121 F. Supp. 758 (D.D.C. 1954); 8 WIGMore, EvmENce $\S \S 2263,2265(5)$ (McNaughton rev. 1961); cf. Holt v. United States, 218 U.S. 245 (1910). 20342 U.S. 165 (1954).

21 In many states the issue has not been raised because prior to Mapp v. Ohio, 367 U.S. 643 (1963), many state courts did not exclude unconstitutionally seized evidence, in reliance upon Wolf v. Colorado, 338 U.S. 25 (1949). Mapp overruled Wolf. 
a search since the police were only "capturing" the air the suspect exhaled. ${ }^{22}$ Other courts have found a search but have called it reasonable because it was made under special circumstances. ${ }^{23}$ In Carroll $v$. United States, the seizure of illegal whiskey from a car was permitted "because the vehicle can be quickly moved out of the locality or jurisdiction in which the warrant must be sought." 24 Here, too, the natural body processes oxidizing the alcohol makes prompt seizure essential. Although in circumstances where the defendant was not under arrest a few courts have excluded chemical test evidence on search and seizure grounds, ${ }^{25}$ the requirements of section 6-205-arrest and reasonable grounds-eliminate that objection.

But, arguably, something more basic is involved than is articulated by these three objections to the admissibility of the test. Ingrained in our legal system is the attitude that a person charged with crime is not required to assume the prosecutor's burden of proving him guilty. Indeed, the very requirements of reasonable cause and particular evidence which justify a search are factors which make state aggressiveness objectionable if it is designed to make the defendant the means of his own conviction. ${ }^{26}$ How to conceptualize this objection to intoxication test statutes has so far eluded both defendants and judges.

In Boyd v. United States ${ }^{27}$ the Court attempted the conceptualization in an equally difficult situation. Under the statute there struck down, the defendant was required either to provide incriminating invoices or to have the Government's allegations concerning them taken as true. The Supreme Court called this dilemma "tantamount to compelling... production" 28 of private papers protected by the privilege against selfincrimination. Its holding, however, linked the fourth and fifth amendments, the Court concluding that this violation of the fifth made the seizure per se "unreasonable" under the fourth. ${ }^{29} \mathrm{~A}$ contemporary court

22 State v. Berg, 76 Ariz. 96, 259 P.2d 261 (1953).

23 People v. Pack, 199 Cal. App. 2d 857, 19 Cal. Reptr. 186 (Dist. Ct. App. 1962); Schutt v. MacDuff, 205 Misc. 43, 127 N.Y.S.2d 116 (Sup. Ct. 1954); cf. Blackford v. United States, 247 F.2d 745 (9th Cir. 1957).

24267 U.S. 132, 153 (1925).

25 State v. Weltha, 228 Iowa 519, 292 N.W. 148 (1940); State v. Kroening, 274 Wis. 266, 79 N.W.2d 810 (1956); cf. Lebel v. Swincicki, 354 Mich. 427, 93 N.W.2d 281 (1958).

26 For example, it is the danger of incrimination that activates the fifth amendment privilege. In England, the Judge's Rules require warning a person of his right not to make a statement only after the police suspect him of the crime under investigation. St. Johnston, The Legal Limitation of the Interrogation of Suspects and Prisoners in England and Wales, 39 J. CRIM. L. \& C. 89, 94 (1948).

27116 U.S. 616 (1886).

$28 \mathrm{Id}$. at 621-22.

29 Id. at 630. 
probably would find this construction theoretically unsatisfactory. But on the basis of an analogy to the coerced confession cases an argument for the constitutional exclusion in criminal proceedings of evidence obtained under the similar dilemma of section 6-205 can be made.30

One important reason for the coerced confession exclusionary rule is to preserve an "accusatorial, adversary trial" by preventing "prosecutorial circumvention of trial safeguards" in the state's effort to produce evidence having "a powerful impact on the triers of fact, substantially increasing the probabilities of conviction."31 In both Rochin v. California $^{32}$ and $M a p p$ v. Ohio ${ }^{33}$ the Court analogized rules governing the admissibility of real evidence to the coerced confession exclusionary rule. Even proponents of statutes like section 6-205 seem to concede that coercion is involved, ${ }^{34}$ but one has called it "refined." 35 Sophisticated coercion has, however, often been struck down. ${ }^{36}$ In Lynumn $v$. Illinois, ${ }^{37}$ for example, a confession was found constitutionally inadmissible because made in response to a statement by the arresting officer that the defendant's relief payments would be cut off and she would lose her children if she did not cooperate. Some writers have argued that since a driver's license is often called a "privilege," taking it away for failure to take a chemical test is not subject to objection..$^{38}$ There is no greater right to a relief check, but the threat of cancellation, because it was used coercively, was sufficient to make the Court reverse the conviction in Lynumn.

However, some courts have implicitly followed a distinction between forcing an affirmative act-the usual coerced confession situation-and

30 See 8 WIGMORE, EvideNCE $\$ \S$ 2184a, 2264 n.4 (McNaughton rev. 1961).

31 Comment, The Coerced Confession Cases In Search of a Rationale, $31 \mathrm{U}$. CHI. L. Rev. 313, 315, 320, 325 (1964). Many of the coerced confession cases also turn to some extent on a desire to exclude evidence of questionable reliability or to deter the police from using brutality. Neither of these objections can be made to the admission of intoxication tests obtained under the procedures of $\S 6-205$. See authorities cited note 5 supra and textual discussion accompanying notes 20-21 supra.

32342 U.S. 165, 173 (1954).

33367 U.S. 643, 656-57 (1961).

34 Dewey, supra note 3; Weinstein, supra note 12, at 543 n.7.

35 Weinstein, supra note 12 , at 543 n.7.

36 Haynes v. Washington, 373 U.S. 503 (1963); Townsend v. Sain, 372 U.S. 293 (1963); Gallegos v. Colorado, 370 U.S. 49 (1962); Blackburn v. Alabama, 361 U.S. 199 (1960); Fikes v. Alabama, 352 U.S. 191 (1957); Leyra v. Denno, 347 U.S. 556 (1954).

37372 U.S. 528 (1963).

38 Mamet, supra note 14, at 257; Slough \&: Wilson, supra note 1, at 701; Comment, 35 Texas L. Rev. 813 (1957); Comment, 17 Wash. \& LeE L. REv. 299 (1960); Note, 1960 WASH. U.L.Q. 84; cf. Proceedings in the Committee on the Uniform Chemical Test for Intoxication Act of the Commissioners on Uniform State Laws, August 23, 1956 (mimeographed transcript). 
simply taking evidence as in the traditional search and seizure. Thus, at the extremes they have condemned compelling a conscious defendant to himself give a urine sample because this required his aid, ${ }^{39}$ and they have sustained a doctor's taking a blood sample from an unconscious defendant because the suspect was passive..$^{40}$

The distinction between these situations does not seem well-considered. It is ultimately premised on a dichotomy between body and mind that concludes that a man's "body" is only acted upon, i.e. searched, while it is only his conscious "will" that acts and can be coerced. Rochin and $M a p p$ are prime examples, however, of the Supreme Court's willingness to extend coerced confession cases beyond verbal acts. In cases involving hypnosis and truth serum,41 the "will" is rendered ineffective and the "body" reveals its secrets, but even where the truth is thus exposed the technique has been held to violate due process. Such cases illustrate that the crucial test is the effect of the evidence on the distribution of the burden of proof between the state and the "whole defendant"-regardless of consciousness, the "will" and like concepts. Similarly, under statutes like the Uniform Vehicle Code section 6-205, the coercive threat of a license suspension is used to force the defendant to permit the police to take a sample of body fluid or breath which may well provide the prosecutor with a statutory presumption of guilt. Applying the coerced confession rationale, the test results should be excluded.

Of course no defendant may be completely uncooperative. In at least two situations he must affirmatively aid the prosecutor. First, he may be required to appear in court, stand up, ${ }^{42}$ try on a blouse ${ }^{43}$ and similarly be identified. ${ }^{44}$ These acts tend to be many inductive steps removed from a finding of guilt. Second, he may be forced to submit records required by law to be kept for a valid independent purpose even if that evidence will lead to his conviction; ${ }^{45}$ however this exception to the fifth

39 Booker v. Cincinnati, 22 Ohio L. Abs. 286, 1 Ohio Supp. 152 (C.P. 1936); Apodaca v. State, 140 Tex. Crim. 593, 146 S.W.2d 381 (1940). But cf. United States v. Nesmith, 121 F. Supp. 758 (D.D.C. 1954).

40 People v. Pack, 199 Cal. App. 2d 857, 19 Cal. Reptr. 186 (Dist. Ct. App. 1962); State v. Sturtevant, 96 N.H. 99, 70 A.2d 909 (1950); State v. Cram, 176 Ore. 577, 160 P.2d 283 (1945). But cf. State v. Kroening, 274 Wis. 266, 79 N.W.2d 810 (1956).

41 Townsend v. Sain, 372 U.S. 293 (1963); Leyra v. Denno, 347 U.S. 556 (1954).

42 Roberson v. United States, 282 F.2d 648 (6th Cir. 1960).

43 Holt v. United States, 218 U.S. 245 (1910).

44 Donigan, op. cit. supra note 2, at 115-23; INBAu, Self-INGRIMination: What Can an Accused Person Be Compelled To Do? (1950).

45 Shapiro v. United States, 335 U.S. 1 (1948); cf. United States v. White, 322 U.S. 694 (1944); Wilson v. United States, 221 U.S. 861 (1911). 
amendment apparently does not apply to evidence relevant only to the crime in question. ${ }^{46}$

The requirement of fingerprinting, often analogized to that of chemical testing, combines the best of each exception; the prints when taken are not, of themselves, proof of guilt in the particular case, and they serve the independent purpose of identification and record keeping. Chemical testing, however, combines the worst of each. There is no independent record-keeping purpose, and, with the statutory presumption, the test of itself is sufficient to shift the burden of proof. The coerced confession rationale is strikingly apposite.

Breithaupt v. Abram ${ }^{47}$ is Supreme Court authority permitting compulsory testing, but it is not dispositive of the issues raised here. The case was heard three years after Rochin and eight years after Wolf $v$. Colorado. ${ }^{48}$ The state court had conceded that taking blood from the defendant while he was unconscious and not under arrest violated his constitutional rights, ${ }^{49}$ but it refused to require exclusion of the evidence on this ground. The case thus raised the issue of the effect of Rochin upon Wolf. The Supreme Court simply reaffirmed Wolf and applied the due process standard of Rochin narrowly, holding that the Justices were not shocked by the sanitary taking of blood. ${ }^{50}$ No consideration of the coerced confession analogy was made.

Subsequent history shows the foundation of Breithaupt has eroded. Since Mapp v. Ohio ${ }^{51}$ overruled Wolf, the illegal seizure of evidence itself violates due process regardless of an independent "shock" to the court. A case with the same facts as Breithaupt would now go the other way. The Breithaupt opinion does suggest, however, the extent to which the Court was impressed with the serious need for deterring drunken driving. ${ }^{52}$ No realistic prediction of judicial behavior in this area should ignore the fact that the courts are aware of the serious social problem

46 See Meltzer, Required Records, The McCarran Act, and the Privilege Against Self-Incrimination, 18 U. CHr. L. REv. 687 (1951); cf. Communist Party of the United States v. United States, No. 17583, D.G. Cir., Dec. 17, 1963.

47352 U.S. 432 (1957).

48338 U.S. 25 (1949). Wolf had held that due process did not require the states to exclude illegally seized evidence in criminal trials.

4958 N.M. 385, 391, 271 P.2d 827, 830 (1954).

$50 \mathrm{Mr}$. Chief Justice Warren, joined by Justices Black and Douglas argued that Rochin required exclusion of all evidence obtained by entering the human body. 352 U.S. at 440 (dissenting opinion).

51367 U.S. 643 (1961).

52352 U.S. at 439 . See also Lee v. State, 187 Kan. 566, 571, 358 P.2d 765, 769 (1961); Schutt v. McDuff, 205 Misc. 43, 46, 127 N.Y.S.2d 116, 121 (Sup. Ct. 1954); Alexander v. State, 305 P.2d 572, 585 (Okla. Crim. App. 1956). 
posed by intoxicated drivers. Of course, no one can doubt this danger. ${ }^{53}$ But citizens have an equally significant interest in preventing "shortcuts to criminal-law enforcement." 54

The use of the criminal process brings into play the great range of protections afforded an accused. If only retention of a license is at stake it should be noted, however, that important factors change. The quantum of proof required for revocation is substantially less than for a criminal conviction. The First Circuit has said, for example, that "reason to believe" the driver intoxicated is a constitutionally sufficient ground for a license revocation. ${ }^{55}$ Although the distinction between civil and criminal penalties may be criticized where as here both sanctions go to the same problem, ${ }^{56}$ by the same showing now required to set in motion the process of chemical testing, a state could, acting in a purely administrative capacity, help keep drunk drivers off the roads. License revocation would be sustained as a technique for highway regulation; it is less likely to be so when invoked solely to obtain a criminal conviction.

Even in practice, statutes using the implied consent theory have been only qualified successes. The Vermont court, in sustaining its statute, said the provisions for procedural due process were so complicated that it was doubtful the end would ever be really achieved..57 A New York court held a recent amendment prevented conviction where the prisoner refused the test-no matter what other proof was available. ${ }^{58}$ The Utah court dismissed two convictions because the defendants had not been given a choice of tests. ${ }^{59}$ Such potential impracticalities, combined with the constitutional uncertainties, cast doubt upon the wisdom and desirability of adopting statutes like Uniform Vehicle Code section 6-205.

53 Estimates vary as to the percentage of accidents involving drunken drivers, but all agree the figure is high. See Campbell, Courts and Prosecutors Are the Weak Link in Preventing Drunken Driving, 46 A.B.A.J. 43 (1960) (cites estimates that it is 50\% or more); Note, 6 BAYLOR L. REv. 404 (1954) (figure 50\% in Texas in 1952); Comment, 35 TEXAS L. REv. 813 (1957) (33\% to 50\% of all accidents).

54 Will, Recent Federal Cases, 44 ChI. BAR Rec. 64 (1962).

55 Wall v. King, 206 F.2d 878, 884 (1st Cir. 1953).

56 See Conway, Is Criminal or Civil Procedure Proper for Enforcement of Traffic Laws? (pts. 1 \& 2), 1959 Wis. L. REv. 418, 1960 Wis. L. REv. 3.

57 State v. Ball, 123 Vt. 26, 179 A.2d 466 (1962). Indeed the court found that the statute negatived its own implied consent provision.

58 People v. Wagonseller, 25 Misc. 2d 217, 205 N.Y.S.2d 933 (Plattsburgh City Ct. $1960)$.

59 Bean v. State, 12 Utah 2d 76, 362 P.2d 750 (1961); Ringwood v. State, 8 Utah 2d 287, 333 P.2d 943 (1959). 